\title{
Authenticating Oral and Memory Variants in Ancient Hebrew Literature ${ }^{1}$
}

Keywords: oral, orality, memory, textuality, variant, scribe, scribal practice, quotation, citation, reproduction

The unending pursuit of more accurate models for understanding text production in Jewish antiquity gave birth in the 1990s to a new sub-discipline. New reflection on the emergence of writing in an oral context moved scholarship away from the longstanding assumption that in some transitional 'moment' ancient Israel changed from a predominantly oral to a predominantly literate culture. Instead, scholars posited long centuries of transition in which the oral and the literate coexisted and, indeed, interacted. The newer model was messy and unpredictable. It imagined texts being composed and transmitted in contexts that were continually impacted by the dynamics of orality, including oral performance, oral reading, and memories of the same. Appreciating the fact that these forces could impact any stage or stages in a text's production and transmission significantly complicated scholarly models of text production. ${ }^{2}$

1. A portion of the research for this paper was conducted in 2014 with the support of an Arts and Humanities Research Council fellowship, which I gratefully acknowledge.

2. This new turn in biblical studies was anticipated by Henrik S. Nyberg, Studien zum Hoseabuche, zugleich ein Beitrag zur Klärung des Problems der Alttestamentlichen Textkritik (Uppsala 1935); Helmer Ringgren, 'Oral and Written Transmission in the Old Testament: Some Observations', Studia Theologica 3 (1949), 34-59; and Birger Gerhardsson, Memory and Manuscript: Oral Tradition and Written Transmission in Rabbinic Judaism and Early Christianity (Lund and Copenhagen 1961). The major influence from outside of biblical studies was the Parry-Lord school in Classics. See especially Milman Parry 'Studies in the Epic 
The majority of book-length studies on 'orality and textuality' - as this sub-discipline has been labelled-have focused on the socio-archaeological dimensions of the question. Lemaire, Jamieson-Drake, Parker, Davies, Schams, Heaton, and Crenshaw have penned major studies on the theme, culminating in 2005 with the appearance of William Schniedewind's synthetic work How the Bible Became a Book. ${ }^{3}$ For all their diversity, these studies pursue a similar body of evidence: proof of expanding education and literacy and their (assumed) major catalysts: centralized administration and urbanization, increased trade specialization, and changing

Technique of Oral Verse-Making. I. Homer and Homeric Style', Harvard Studies in Classical Philology 41 (1930), 73-147; idem., 'Studies in the Epic Technique of Oral Verse-Making. II. The Homeric Language as the Language of Oral Poetry', Harvard Studies in Classical Philology 43 (1932), 1-50.

3. André Lemaire, Les Écoles et la Formation de la Bible dans l'ancien Israël (Orbis biblicus et orientalis 39, Göttingen 1981); David Jamieson-Drake, Scribes and Schools in Monarchic Judah: A Socio-Archeological Approach (Social World of Biblical Antiquity 9, Sheffield 1991); Simon Parker, Stories in Scripture and Inscriptions: Comparative Studies in Northwest Semitic Inscriptions and the Hebrew Bible (New York 1997); Philip Davies, Scribes and Schools: The Canonization of the Hebrew Scriptures (Louisville 1998); Christine Schams, Jewish Scribes in the Second-Temple Period (JSOT Supplement Series 291, Sheffield 1998); Eric W. Heaton, The School Tradition of the Old Testament: The Bampton Lectures for 1994 (Oxford 1994); James Crenshaw, Education in Ancient Israel: Across the Deafening Silence (New York 1998); William M. Schniedewind, How the Bible Became a Book: The Textualization of Ancient Israel (Cambridge 2005). I have passed over a few studies that were not widely or positively received, e.g. Alan Dundes, Holy Writ as Oral Lit: The Bible as Folklore (Lanham, MA 1999). 
economic structures. Because of their socio-archaeological approach to the question, they only touch lightly on internal evidence regarding text production from the literature of the Hebrew Bible itself. A second stream of research does highlight the text-internal evidence, seeking traces of oral performance in ancient Hebrew literary conventions and the caprices of transmission history. Important voices from this direction include Susan Niditch, Raymond Person, Robert Kawashima, and Frank Polak. ${ }^{4}$ The two streams were not conjoined until 2005 when David Carr

4. Susan Niditich, Oral World and Written Word: Ancient Israelite Literature (Library of Ancient Israel, Louisville 1996); idem., 'Hebrew Bible and Oral Literature: Misconceptions and New Directions', in Annette Weissenrieder and Robert B. Coote (eds), The Interface of Orality and Writing: Speaking, Seeing, Writing in the Shaping of New Genres (Tübingen 2010), 3-18; Raymond F. Person, Jr., 'The Ancient Israelite Scribe as Performer', Journal of Biblical Literature 117:4 (1998), 601-609; idem., The Deuteronomic History and the Book of Chronicles: Scribal Works in an Oral World (Ancient Israel and its Literature 6, Atlanta 2010); idem., 'Text Criticism as a Lens for Understanding the Transmission of Ancient Texts in their Oral Environments', in Brian Schmidt (ed) Contextualizing Israel's Sacred Writings: Ancient Literacy, Orality, and Literary Production (Ancient Israel and its Literature 22, Atlanta 2015), 197-216; Robert Kawashima, Biblical Narrative and Death of the Rhapsode (Bloomington 2004); Frank H. Polak has produced numerous article-length studies on sociolinguistics and orality. The most foundational are 'Sociolinguistics, a Key to the Typology and the Social Background of Biblical Hebrew', Hebrew Studies 47 (2006), 128-36; idem., 'The Book of Samuel and the Deuteronomist: A Syntactic-Stylistic Analysis', in C. Schäfer-Lichtenberger (ed), The Books of Samuel and the Deuteronomists (Beiträge zur Wissenschaft vom Alten (und Neuen) Testament 188, Stuttgart 2010), 38-54; idem., 'Oral Substratum, Language Usage, and Thematic Flow in 
released his major monograph, Writing on the Tablet of the Heart. ${ }^{5}$

Despite its obvious and immediate implications for textual criticism, studies of orality and textuality have not emphasized this dimension of its consequences. Fortunate exceptions can be

found in the work of Raymond Person Jr. and David Carr, in particular. In two essays by Person and one by Carr-all three of which might be called diagnostic articles - they describe the kinds of evidence that indicate the influence of orality or memory in a text's written features and classify types of oral and memory variants. The purpose of this essay is to reconsider the authentication of oral and memory variants. In the first part of the essay, I briefly set out Person's and Carr's text-critical proposals. In the second part, I bring a particular set of text-internal evidence to bear that has direct implications for their proposals, namely quotations and citations. In the third part of the essay, I explore the implications of this evidence on the authentication and analysis of oral- and memory-variants.

\subsection{Orality and Textuality}

\subsection{Raymond Person, Jr. (1998, 2010, 2015)}

In his 1998 article 'The Ancient Israelite Scribe as Performer', Raymond Person first explored the implications of Susan Niditch's proposals in Oral World and Written Word on textual the Abraham-Jacob Narrative', in Brian Schmidt (ed), Contextualizing Israel's Sacred Writings: Ancient Literacy, Orality, and Literary Production (Ancient Israel and its Literature 22, Atlanta 2015), 217-238.

5. Carr's monograph was followed quickly by the equally important Scribal Culture and the Making of the Hebrew Bible by Karl van der Toorn (Cambridge, MA 2007). Van der Toorn's work is focused on written processes more than oral ones. 
criticism. Niditch noted that "[t]he transmission of this tradition [the Hebrew Bible] may well have involved complex interplays between written and oral processes. ${ }^{96}$ Person's objective was to 'develop Niditch's suggestion more fully', arguing that

The ancient Israelite Scribes were literate members of a primarily oral society. As members of a primarily oral society, they undertook even their literate activity - that is, the copying of texts - with an oral mindset. When they copied their texts, the ancient Israelite scribes did not slavishly write the texts word by word, but preserved the texts' meaning for the ongoing life of the community in much the same way that performers of oral epic re-present the stable, yet dynamic, tradition to their communities. In this sense, the ancient Israelite scribes were not mere copyists but were also performers. ${ }^{7}$

Person attributed many textual variants that were generated in the process of written transmission to this 'oral mentality.' He cited synonymous readings, additions providing specificity, and unconscious additions, as examples of this phenomenon. ${ }^{8}$ Such differences 'cannot be accounted

\footnotetext{
6. Oral World, 77.

7. 'Ancient Israelite Scribe', 602.

8. Person draws examples from the works of Shamaryahu Talmon and Emanuel Tov. See, especially, Talmon, 'Synonymous Readings in the Textual Traditions of the Old Testament', Scripta Hierosolymitana 8 (1961), 335-81; idem., 'Observations on Variant Readings in the Isaiah Scroll (1 QIsa')', ch in The World of Qumran from Within: Collected Studies (Jerusalem 1989); Emanuel Tov, 'Some Aspects of the Textual and Literary History of the Book of Jeremiah', in P.-M. Bogaert (ed), Le livre de Jérémie. Le prophète et son milieu, les oracles et leur transmission (Bibliotheca ephemeridum theologicarum lovaniensium 56, Leuven 1981); idem., 'The Literary History of the Book of Jeremiah in the Light of its Textual History', in 
for as being deliberate or due to slips of the pen or lapses of memory' and therefore, '[t]hese alternative readings are not really "variants". ${ }^{9}$ As Person says,

When we take seriously the possibility that even the literate activity of copying texts was influenced by an oral mentality, we may begin to understand more clearly how "careful" scribes in ancient Israel produced texts with what appear to us to be "variants." Rather than copying the texts verbatim in a good literate manner (as we expect of ourselves), the ancient Israelite scribes performed the texts faithfully for their communities in their act of copying $\ldots^{10}$

Person revisited this issue in his 2010 monograph, The Deuteronomic History and the Book of Chronicles: Scribal Works in an Oral World, and in a 2015 essay, 'Text Criticism as a Lens for Understanding the Transmission of Ancient Texts in their Oral Environments.' In 'Text Criticism' (which sums up much of the evidence presented in The Deuteronomic History), he explicitly combined the Parry-Lord observation that multiformity is a characteristic of oral tradition with the text-critical observation that textual plurality was the norm in ancient Israel prior to the Rabbinic age. In Person's words:

Thus, as texts in a primarily oral society like ancient Israel, each manuscript represents the broader tradition as an imperfect instantiation of the broader tradition that existed, on the one

Jeffery Tigay (ed), Empirical Models for Biblical Criticism (Philadelphia 1985), 211-39; idem., Textual Criticism of the Hebrew Bible (Minneapolis 1992), 319-27. Compare Raymond Person, Jr., The Kings/Isaiah and Kings/Jeremiah Recensions (Beihefte zur Zeitschrift für die alttestamentliche Wissenschaft 252, Berlin 1997), 8-79.

9. 'Observations of Variant Readings', 122, 126.

10. Ibid, 608-9 
hand, in the interplay of coexisting parallel written texts, none of which alone can possibly represent the fullness of the tradition, and, on the other hand, in the mental text in the collective memory of the people. ${ }^{11}$

The majority of the article recites examples from Homeric epics, Old English literature, the Thousand and One Nights, and the Dead Sea scrolls, offered as salient equivalents that establish the plausibility of his model. Person concludes with an exhortation:

Thus, we as scholars of this ancient literature should strive to discern how this literature that from our modern perspective appears to contain numerous "additions," "omissions," and "substitutions" was nevertheless understood by the ancients as faithful representations of this broader tradition by our drawing from the insights of multiformity in the comparative study of oral traditions and the insight of textual plurality from text criticism. ${ }^{12}$

\subsection{David Carr (2005, 2015)}

Also building on the foundation laid by Susan Niditch, David Carr has offered a more rigorous model for understanding the relationship of the oral to the written in Israelite antiquity. In his book Writing on the Tablet of the Heart, ${ }^{13}$ Carr suggests that the emergence of writing and the

\footnotetext{
11. 'Text Criticism as a Lens', 197. It is not entirely clear what is meant by 'broader tradition' either in this article or in Person's monograph Deuteronomic History (esp. 69-86). With respect to Samuel-Kings and Chronicles it seems to refer to the basic story in a (mostly) particular order, excluding ideology, argument, or rhetorical thrust.

12. As one can see from these quotations, Person makes pivotal assumptions about ancient attitudes toward textual variance and the social contexts in which textual variances could have occurred.
} 
scribal profession was not primarily motivated by the impulse to generate and preserve texts. It was an enterprize in 'educational enculturation' in which scribes and elite leaders internalized and developed a distinct body of literature that preserved the traditions essential to creating and protecting identity, 'writing on the tablet of the heart' to use Carr's turn of phrase. ${ }^{14}$ The interplay between oral performance, memorization, and writing in this enculturation process was a key factor in the production and transmission of ancient Hebrew literature. ${ }^{15}$

Carr outlines an associative dynamic between orality and textuality in the cultures of Sumer,

13. David Carr, Writing on the Tablet of the Heart: Origins of Scripture and Literature (New York 2005).

14. Writing, 7-9. The importance of 'schools' as the vehicle for the development of literature cannot be overestimated. 'School,' in Carr's nomenclature, is an ample word. It encompasses institutions as small as 'home schools' within priests' families to those as large as the Temple. It also takes in public and private education, like private scribal schools and public Sabbath gatherings (Writing, 177-285).

15. '[T]he writing of ancient literary texts was largely in the service of a process of memorizing them in school and other contexts. At least up through the Second Temple Period of Jewish scribalism, writing was not opposed to memory but served it ... biblical literature, qua written literature, was written in a context where the memorization and performance of ancient tradition was writing-supported, so that one internalized and/or performed biblical traditions through the help of written manuscripts'. Carr, 'Orality, Textuality, and Memory: The State of Biblical Studies', in Brian Schmidt (ed), Contextualizing Israel's Sacred Writings: Ancient Literacy, Orality, and Literary Production (Ancient Israel and its Literature 22, Atlanta 2015), 169. 
Egypt, Greece, and the early Jewish and Christian communities, from the third millennium BCE to the second century CE. Four major elements of ancient Near Eastern education contributed to identity production: scribal instruction, based on a curriculum of culturally central texts; social and ideological enculturation by means of these texts; the resulting social cohesion of the elites educated by these means; and the cultural continuity achieved by the transmission of longduration foundational texts. ${ }^{16}$ Education into these texts and traditions included far more than reading and copying. It included recitation and memorization, mechanisms that both preserved the traditions and empowered their on-going adaptation. ${ }^{17}$ In Carr's words:

... we must conceptualize textual production as part of a broader scribal matrix, a matrix where-in addition to writing administrative documents-scribe/teachers (ummia) collected and updated a limited corpus of standard texts, inscribed those texts on stable media, and inscribed those texts on the minds of students for recitation and socialization. Both sorts of inscription-inscription on humans and tablets-were key parts of the scribal task. ${ }^{18}$

\footnotetext{
16. Writing, 20-34.

17. Ibid, 34-39.

18. Ibid, 18. A fundamental assumption of Niditch's model is that the Bible represents the
} surviving results of a long cultural investment in reciting, writing, and rewriting the ancient traditions recorded in it. This is basic to Carr's view as well, which is why he emphasizes that the Bible, like Homer, is a 'long duration' text (Writing, 5, 10, 19, etc.; 'Orality, Textuality, and Memory', 169-70). In this view, the stories and poems that now make up the Hebrew Bible survived, in part, due to their persistent use in ancient Israelite educational circles (Writing, 16173). As Frank Polak and Reinhard Kratz have emphasized, this model does not account for the 
Carr takes up the important implications of his model for textual-criticism in his 2015 article 'Orality, Textuality, and Memory.' In this essay, Carr begins with Milman Parry's and James Zetzel's observations that certain changes or variations produced during literary transmission 'are not typical of transmission processes focused exclusively on visual copying.' ${ }^{19}$ Textual variants typical of visual copying include confused letters, skipped lines, transposed letters, and

strong anti-establishment traits in the HB. If the HB represents Israel's traditions of longduration, passed down from generation to generation among elites, how are we to account for its powerful anti-monarchic, anti-upperclass, anti-priestly, anti-prophetic, and anti-scribal tendencies? See, for example, Frank H. Polak, 'Book, Scribe, and Bard: Oral Discourse and Written Scholarship in Recent Biblical Scholarship', Prooftexts 31 (2011), 118-40, esp. 130-32; Reinhard G. Kratz, Historisches und biblisches Israel: Drei Überblicke zum Alten Testament (Tübingen 2013), esp. 79-99. Carr's model is more nuanced than Niditch's in this respect; he does detect the existence of an alternative enculturation model reflected in prophetic texts like Isa $5: 21 ; 29: 14-15 ; 30: 1-2 ;$ Jer 8:8-9.

19. Carr, 'Orality, Textuality, and Memory', 162. Parry, 'Studies in Epic Technique'; James Zetzel, 'Religion, Rhetoric, and Editorial Technique: Reconstructing the Classics', in George Bornstein and Ralph Williams (eds), Palimpsests: Editorial Theory in the Humanities (Ann Arbor 1993), 99-120. The earliest scholars whom I have been able to identify who sought evidence of oral performance and memory 'slips' in variant readings (excluding Milman Parry) were Egyptologists Aksel Volten, Studien zum Weisheitsbuch des Anii (Kongelige Danske videnskabernes selskab, Historisk-filologiske meddelelser 47, Copenhagen 1937) and Baudouin van de Walle, La transmission des textes littéraires égyptiens (avec une annexe de Georges Posener) (Brussels 1948). 
so forth. Other variants are aural, particular to the oral recitation or performance of written texts. The exchange of a word with another of a similar sound, for example, is a distinctively aural variant. However, there is another class of variant that appears to be caused by slips of the mind, what Carr terms 'memory variants.' Parry included such variants within the category 'oral,' but, as Carr observes, they are different in kind. Among memory variants, Carr includes synonym substitutions, rearrangement of poetic lines (in cases where the lines still scan), insertion and excision of minor particles, and so forth. ${ }^{20}$ These are, in Parry's terminology, good variants. They are not errors, as such. They are differences, to be sure, but because they 'fit ancient diction, are grammatically permissible, and conform to the cognitive and ideological rules of ancient biblical literature' they represent an 'effort after meaning. ${ }^{21}$

20. Carr takes a significant step beyond Parry, Ringgren, and Person in that he includes certain expansions and harmonizations as memory variants. Carr has argued that, in many cases, expansions and harmonizations are meant to reveal the coherence assumed to inhere to the Torah. As such, their content is derived from other scripture and, typically from memory. '[T]radents believed themselves to be making the Torah yet truer to itself than it was before. In other words, the harmonizations and coordinations were a form of "hyper-memorization." They were expansionist variations, but believed to be truer to the tradition than were earlier copies.' 'Orality, Textuality, and Memory', 171. See also 'Scribal Processes of Coordination/Harmonization and the Formation of the First Hexateuch(s)', in Thomas Dozeman et al. (eds), The Pentateuch: International Perspectives on Current Research (Forschungen zum Alten Testament 1:78, Tübingen 2011), 63-82.

21. 'Orality, Textuality, and Memory', 166-67; likewise, Talmon, 'Observations on Variant Readings', 126-27. 
Carr argues that the binary opposition between textuality and orality, or scribalism and the 'oral mindset,' is incomplete. A third pole, that of memory, is a necessary complement to orality and textuality. ${ }^{22}$ What is reflected in any given manuscript or book is a complex of traits, some resulting from writing and copying, some resulting from oral performance, and some resulting from the vagaries of memory. The composition and transmission of the Hebrew Bible (hereafter 'HB') and other Second Temple literature was effected, in most cases, in the same way: by a combination of causes. ${ }^{23}$ When texts were written, rewritten, or transmitted, some source texts or portions of source texts were retrieved by physically consulting the original, some by listening to a recitation, and some by memory. ${ }^{24}$

22. Ibid, 164; Writing, 234-39. This point has also been made by numerous text-critics, albeit in more oblique ways. See, e.g. James Sanders, 'Stability and Fluidity in Text and Canon', in G. J. Norton and S. Pisano (eds), Traditions of the Text: Studies Offered to Dominique Barthélemy in Celebration of his 70th Birthday (Orbis biblicus et orientalis 109, Freiburg and Göttingen 1991), 203-17; Emanuel Tov, 'The Status of the Masoretic Text in Modern Text Editions of the Hebrew Bible', in Lee MacDonald and James Sanders (eds), The Canon Debate (Peabody, MA 2002), $234-63$.

23. For examples from the Torah and the Temple Scroll (11QT) see Carr, 'Scribal Processes', 63-82; idem, 'Orality, Textuality, and Memory', 167-69.

24. In support of their model broadly, Niditch and Carr both rehearse the proposal that written sources were either too rare or too 'unwieldy' to be referenced by ancient biblical writers in the processes of writing or editing (Oral World, 113; Writing, 3-4, and throughout; 'Orality, Textuality, and Memory', 168-69). Note, in particular, Alan Millard's reservations about this assumption, expressed in his review of Niditch: 'Oral Word and Written Word', Journal of 
The notion that orality and memory can influence not only textual production but also transmission has been widely acknowledged in biblical textual-criticism for quite a long time but without the nuance brought to it by Person and Carr. Person's and Carr's contributions have contributed a more refined set of considerations for deciding whether or not a variant is due to graphic error or 'oral mindset' and for distinguishing between graphic-, aural-, and memoryvariants. Their proposals are reasonable, even unremarkable (on reflection). However, when we compare the text-critical evidence with evidence from other species of textual reproduction, a different portrait appears. What we discover is that the kinds of difference that Person and Carr categorize as having been generated by failure-whether failures in copying, in oral communication, or in memory ${ }^{25}$-are, in fact, normal and productive parts of all types of textual reproduction in Jewish antiquity. ${ }^{26}$

\subsection{Quotation, Citation, and Identicality}

In simple terms, a quotation relocates a segment of speech or writing, removing it from its original communication context and embedding it in another. Less simply, whether in the voice

Theological Studies 49:2 (1998), 699-705 and the discussion in Kratz, Historisches und biblisches Israel, 181-274.

25. I say 'failure' not 'error'. Most oral and memory variants are, as we have said, 'good' variants. Nonetheless they represent failures of perfect memory or failures of perfect hearing, even if blithely tolerated.

26. Cf. Michael V. Fox, 'The Identification of Quotations in Biblical Literature', Zeitschrift für die alttestamentliche Wissenschaft 92:3 (1980), 416-31. 
of a narrator or a character, a quotation is a speech or thought or writing that reports another speech or thought or writing that has been communicated already in real or narrative time. ${ }^{27}$ Speaking to a present communication context while, simultaneously, evoking another context, which usually manifests differences in features like time, place, speaking voice, audience, and stylistic register, creates some startling complexities in the form and function of quotations.

Classical Hebrew, of course, does not possess anything like the inverted comma for indicating the boundaries of a quotation. Instead, it has to make use of a number of less-wieldy techniques to distinguish quotations from their context, on which there is a wide body of important linguistic and literary scholarship. ${ }^{28}$ The discreteness of quotations, though, is not directly pertinent to my argument. The 'literalness' or identicality of quotations, however, is central to this inquiry. Identicality refers to the degree in which a quote is a perfect

27. Cynthia L. Miller, The Representation of Speech in Biblical Hebrew Narrative: A Linguistic Analysis (Harvard Semitic Monographs 55, Atlanta 1996; reprinted with a new afterword in 2003), 3. Thus, in literature, which is flexible in its presentation of time, one can quote even if the original discourse has not yet been presented to the reader (prospective quotation).

28. E.g. Gideon Goldenberg, 'On Direct Speech and the Hebrew Bible', in Karel Jongeling et al., Studies in Hebrew \& Aramaic Syntax: Presented to professor J. Hoftijzer on the Occasion of His Sixty-Fifth Birthday (Leiden 1991), 79-96; George Savran, Telling and Retelling: Quotation in Biblical Narrative (Bloomington 1988); Miller, Representation of Speech; Frank Polak, 'The Style of Dialogue in Biblical Prose Narrative', Journal of the Ancient Near Eastern Society 28 (2001), 53-95; Kevin L. Spawn, 'As It Is Written' and Other Citation Formulae in the Old Testament: Their Use, Development, Syntax, and Significance (Beihefte zur Zeitschrift für die alttestamentliche Wissenschaft 311, Berlin 2001). 
representation of the quoted speech: the same words presented with the same morphology and in the same order. ${ }^{29}$ As moderns, we tend to expect identicality, particularly in capitalist cultures with their deep-seated interest in intellectual property. ${ }^{30}$ Despite this, identicality is not an absolute requirement of quotation. If it were, techniques like free indirect discourse would be impossible. ${ }^{31}$ Indeed, perfect identicality is rare in the HB. ${ }^{32}$ Quotations, even direct quotations, do not just reproduce the same graphemes in the same order. They almost always manifest some degree of modification, referred to by the neutral terms 'difference' or 'dissimilarity., 33

29. Stefan Morawski, 'The Basic Functions of Quotation', in Algirdas J. Greimas (ed), Sign, Language and Culture (The Hague 1970), 691.

30. The assumption of a standard of identicality is commonplace in the literature on quotation and discourse. See, for example, Willard V. Quine, Word and Object (Cambridge, MA 1969), 141-42; Barbara H. Partee, 'The Syntax and Semantics of Quotation', in Stephen R. Anderson and Paul Kiparsky (eds), A Festschrift for Morris Halle (New York 1973), 410-18, esp. 415; and Gérard Genette, Figures III (Paris 1973), 186-89.

31. Herbert H. Clark and Richard R. Gerrig, 'Quotations as Demonstrations', Language 66 (1990), 764-805; Meir Sternberg, 'Point of View and the Indirections of Direct Speech', Language and Style 5:2 (1982), 68 and throughout; idem., 'Proteus in Quotation-Land: Mimesis and the Forms of Reported Discourse', Poetics Today 3:2 (1982), 107-156, esp. 110-19. If the source of a quotation is known to a reader and compared with the quoting text, literalness can assist in establishing the boundaries of a quotation. In this way, literalness can be a complement to discreteness.

32. Exodus 32:4 || 32:8 and 1 Kings 19:9 || 19:13 exemplify the rare identical quotation. (My thanks to George Nichol for pointing out the latter example.) 
Genesis 24 recounts a tale in which Abraham sends his servant, 'the oldest in his household' (v. 1), to Nahor in Mesopotamia to find a wife for his son Isaac from among his kindred. Having identified the right woman, Rachel, the servant reveals the purpose of his quest to her brother Laban. Reciting Abraham's instructions, he says:

${ }^{40}$ But he said to me, 'Yhwh (יהוה), before whom I walk, will send his angel with you (שלחלח and he will make your way successful. You will take a wife for my son (ולקחת אשה לבני) from my kindred and from my father's house (ממשפחתי ומבית אבי). ${ }^{41}$ Then you will be free from my oath (אז תנקה מאלתי), when you come to my kindred; even if they will not give her to you (ואם-לא יתנו לך), you will be free from my oath (והיית ננקי מאלתי.'

Abraham's words, recounted earlier in the chapter, were these (similar locutions indicated):

${ }^{7}$ Yhwh (יהוה), the God of heaven, who took me from my father's house (מבית אבי) and from the land of my birth, and who spoke to me and swore to me, 'To your offspring I will give this land,' he will send his angel before you (הוא ישלח מלאכו לפניך); you shall take a wife for my son from there (ולקחת אשה לבני משם). ${ }^{8}$ But if the woman is not willing to follow you (ואם־לא תאבה האשה ללכת אחריך), then you will be free from this oath of mine (ונקית משבעתי זאת); only you must not take my son back there.'

There are a number of significant differences between these two utterances, as they are presented. Abraham is deeply concerned, that Isaac neither returns to Mesopotamia nor marries a

33. On the importance of the presentation of quoted speech and the functional parameters of identicality see esp. Meir Sternberg, 'Proteus in Quotation-Land', 107-256; 'Point of View', 67117; cf. also Robert Sokolowski, Pictures, Quotations, and Distinctions. Fourteen Essays in Phenomenology (Notre Dame and London 1992), 27-51. 
local Canaanite girl. The servant makes clear that Abraham wants Isaac's bride to be from his kin, but he neither mentions the command to keep Isaac far from Mesopotamia, nor Abraham's special relationship to God, omitting these potentially insulting parts of the original command. ${ }^{34}$ The servant adds to Abraham's words as well. The line 'make your way successful' is his own unique addition and a prominent theme throughout his speech (צל" other two phrases that do not appear in Abraham's original instruction- 'before whom I walk' a (אשר־התהלכתי לפניו) and 'when you come to my kindred' (כי תבוא אל־משפחתי)-are variations on prominent phrases in the various accounts of Abraham's covenant with Yhwh (see esp. Gen. 17:1; 12:1), now conflated with Abraham's words. This is not without basis, since Abraham himself alludes to the covenant in v. 7a. Finally, the servant's quotation changes the original utterance. Some changes are contextual adaptations; they smooth and clarify the quotation for its new audience and context ('he' > 'Yhwh'; 'get a wife ... from my kindred' > 'get a wife ... from there'); others are word substitutions (e.g. 'from my oath,' משבעתי > 'from my oath,' 'מאלתי), or replacements (ואם־לא תאבה האשה ללכת אחריד, 'the woman is not willing to follow you' > ואם-לא יתנו לד, 'they will not give [her] to you'), or repetitions (ונקית משבעתי זאת, 'you will be free from this oath of mine,' in 24:8 is repeated twice: תנקה מאלתי, 'you will be free from my oath'; והיית נקי מאלתי, 'you will be free from my oath,' 24:41a and 41b). Taken together, these differences serve to persuade Nahor to entrust Rachel to the servant, who proposes to carry her off to a faraway land and an unknown groom. The servant's clever adaptations to Abraham's words, reinforce two themes: Yhwh's providential care for the servant's journey, implying that the same care will be extended to Rachel should she be entrusted to the servant, and the bond of blood that binds Nahor to Abraham and, implicitly, Rachel to Isaac (esp. 'birthplace,' 'father's

34. George Savran, 'The Character as Narrator in Biblical Narrative', Prooftexts 5 (1985), 17, esp. 4-5; Meir Sternberg, The Poetics of Biblical Narrative: Ideological Literature and the Drama of Reading (Bloomington 1985), 147. 
house,' 'kindred'). ${ }^{35}$

This example shows numerous types of dissimilarity: (a) morphological differences; (b) the substitution of a word for a synonym; (c) addition of new words; (c) omission of words; (d) reordering of the quoted elements (words, phrases, clauses); (e) conflation of elements that are not juxtaposed in the original communication; and (f) repetition of elements. In the history of modern criticism, some have seen little or no diachronic development in this chapter. ${ }^{36}$ Others have posited a shorter version of the story that was subsequently expanded. ${ }^{37}$ In both models the

35. It should be noted that most of the second half of Gen. 24 (not just the servant's quotation) is re-presentation and adaptation of the first half: vv. 37-41 II 2-9 (esp., 3-8); vv. 4244 || 12-14; vv. 45-46 || 15-20; vv. 47-48 || 22-27. See August Dillmann, Genesis: Critically and Exegetically Expounded (Edinburgh 1897 [German original 1892]), 167-68.

36. E.g., Dillmann, Genesis, 157-59; Julius Wellhausen, Die Composition des Hexateuch und der Historischen Bücher des alten Testament (Berlin 1889), 29-30; Simon B. Parker, 'The Historical Composition of KRT and the Cult of EL', Zeitschrift für die alttestamentliche Wissenschaft 89 (1977), 161-75; Alexander Rofé, 'La composizione de Gen 24', Bibbia e oriente 23 (1981), 161-65; Claus Westermann, Genesis 37-50 (Continental Commentary, Minneapolis 1986 [German original 1982]), 382-91; Kenneth T. Aitken, 'The Wooing of Rebekah: A Study in the Development of the Tradition', Journal for the Study of the Old Testament 30 (1984), 3-23; Reinhard G. Kratz, Composition of the Historical Books of the Old Testament (London 2005 [German original 2010]), 272-74.

37. E.g., Christoph Levin, Der Jahwist (Forschungen zur Religion und Literatur des Alten und Neuen Testaments 157, Göttingen 1993), 184-96; John Skinner, A Critical and Exegetical Commentary on Genesis (International Critical Commentary, Edinburgh 1910), 340-41. 
writer of vv. 40-41 had the words of Abraham in vv. 7-8 to hand, so the differences must be regarded as deliberate.

Particularly telling, regarding the conventions of identicality, are those cases in which characters quote themselves, likewise those cases in which characters quote others back to themselves. Examples of both can be found in Judah's speech before Joseph during their second trip to Egypt (Gen. 44:16-34). Judah pleads with Joseph to show mercy, not just on Benjamin in whose sack Joseph's divining-cup was located, but on Jacob who loves Benjamin.

In Gen. 44, Judah quotes Joseph to himself:

${ }^{19} \mathrm{My}$ lord asked his servants, saying, 'Have you a father or a brother?' ${ }^{20} \mathrm{And}$ we said to my lord, 'We have a father, an old man, and a young brother, the child of his old age. His brother is dead; he alone is left of his mother's children, and his father loves him. ${ }^{21}$ Then you said to your servants, 'Bring him down to me, so that I may set my eyes on him (הורדהו אלי ואשימה עיני עליו).'

The quotation is a terse summary of Joseph's lengthy instructions in 42:14-20. Joseph gives this command more than once, the closest parallel being 42:20a (cf. v. 16):

... ${ }^{20}$ and bring your youngest brother to me (ואת־אחיכם הקטן תביאו אלי). Thus your words will be verified, and you shall not die.' And they agreed to do so.

In this brief quotation, Judah omits words (e.g., הקטן), adds new words (e.g., ואשימה עיני עליו), and substitutes a word (e.g., ירו"א >רבד). None of these are significant semantic alterations; they are alternative ways of expressing the same content or adaptations to the new communication context. Nonetheless, the adapted quotation is more suitable to Judah's suasive purpose, as we will see.

Judah then quotes himself in 44:32, repeating a promise he made to his father Jacob. Judah pledged to protect Benjamin (Gen. 43:9), a pledge that comprised fourteen of the thirty-six words 
of his speech to Jacob (Gen. 43:8-10). Judah repeats the pledge to Joseph in a succinct eight words.

${ }^{43.8} \mathrm{Judah}$ said to Israel his father ... ${ }^{96} \mathrm{I}$ will be his pledge. You may hold me accountable. If I do not return him to you (אם-לא הביאתיו אליך) and set him before you, then I shall bear your blame (וחטאתי לך) forever (כל־הימים).'

${ }^{44.32}$ Indeed, your servant has pledged himself for the boy before my father saying, 'If I do not return him to you (אם-לא אביאנו אליך), then I will bear my father's blame (וחטאתי) לאבי) forever (כל־הימים).'

In this quotation, Judah substitutes 'your' (ד-) with 'my father's' (לאבי), omits 'and set him before you' (והצגתיו לפניך), and alters the morphology of the perf. verb הביאתיו to impf. אביאנו.

All the differences between Judah's quotations and the original utterances reflect the different communication context. The emphasis of Judah's pledge to Jacob rested equally on the likelihood that Judah could return Benjamin to his father and the burden of guilt that he was willing to shoulder should he fail to do so. Before Joseph though, Judah stresses his filial piety, laying the responsibility for both Benjamin's and Jacob's welfare on Joseph. Again and again, Judah underlines the bond between father and son (esp. 44:20-23) and imputes Joseph with Jacob's certain death should he not relent (esp. 44:30-31). ${ }^{38}$

38. Sternberg, Poetics, 174, 300, 306-7; Savran, 'Character', 7. The same comments regarding the diachronic development of Gen 24 offered above apply to Gen. 44 . If anything, they are simplified because most critics detect little if any redactional intervention in ch 44 . See e.g. Levin, Der Jahwist, 293-97; Konrad Schmid, 'Die Josephsgeschichte im Pentateuch', in Jan Gertz et al. (eds), Abschied vom Jahwisten. Die Komposition des Hexateuch in der jüngsten Diskussion (Beihefte zur Zeitschrift für die alttestamentliche Wissenschaft 315, Berlin and New 
In the forgoing examples, when characters quotes themselves or others they always do so with variation. Some of these variances are due to pressures exerted by the new communication context, but others are not. They are applied at the writers' impetus and discretion.

The preceding examples are all cases of text-production. That is, the dissimilarities between the utterances and their quotations were created in the process of composing the texts. The same results can be found, though, with examples of inner-biblical citations, which present themselves as copies of pre-existing textual material. In these cases, the narrator or a character quotes from another text, offering the citation as an act of transmission. Inner-biblical citations manifest the same kinds of dissimilarity that we have observed in direct quotations of speech. Indeed, as with quotations, inner-biblical citations that manifest a high degree of identicality are rather rare. A modest example of the normal practice of citation is found in the story of Josiah's reform, in 2 Kings 23:21 (II 2 Chron. 35:1, 18-19):

${ }^{21}$ The king commanded all the people saying, "keep the Passover of Yhwh your God" (עשו פסח ליהוה אלהיכם), as is written in this covenant scroll.'

The closest exemplar to the king's quote is found in Deut. 16:1a:

I Observe the month of Abib by keeping the Passover of Yhwh your God (ושית פסח ליהוה אלהיך).

The points of dissimilarity are slight. The graphemes of the source were altered in two respects: the $2 d$ per. sing. verb (ועשית) and pronoun (ד-) are both rendered in the pl. Also, the verb in Deut. 16:1 (עששית) is a perf.; in 2 Kings 23:21 it is an impv. (עשו). These are surface-structure differences. The referent of the $2 \mathrm{~d}$ per. sing. forms in Deut. 16:1 is the people as a whole, and the perf. verb has impv. force. The differences, then, are not semantic; they are morphological and York 2002), 83-118. 
graphic. ${ }^{39}$ Whether or not the writer of 2 Kings 23:21 had a written copy of Deut. 16:1 to hand or not is not important at this juncture. However the writer of 2 Kings 23 knew the law that is also recorded in Deut 16:1a (whether embedded in memory, read or recited by an assistant, or copied from a scroll), it was replicated differently.

More typical, is Joshua's quotation of 'the law of Moses' in Josh. 8:30-31. Having entered Canaan and conquered Jericho and Ai, Joshua set up an altar to Yhwh:

${ }^{30}$ Then Joshua built an altar to Yhwh (יבנה ... מזבח ליהוה), the God of Israel, on Mount Ebal, ${ }^{31}$ just as Moses the servant of Yhwh commanded the sons of Israel. As it is written in [the scroll of ${ }^{40}$ ] the law of Moses, "an altar of undressed stones, on which no iron tool

39. The diachronic relationship between Deut. 16:1 and 2 King 23:21 is complicated by the fact that both verses are commonly regarded as part of a set of redactional expansions to their literary contexts. See e.g. comments in Hermann Spiekermann, Juda unter Assur in der Sargonidenzeit (Forschungen zur Religion und Literatur des Alten und Neuen Testaments 129, Göttingen 1982), 130-37; Reinhard G. Kratz, Composition, 122, 153-58, 169; Shimon Gesundheit, Three Times a Year: Studies on Festival Legislation in the Pentateuch (Forschungen zum alten Testament 1:82; Tübingen 2012), 96-166; and especially, Bernard Levinson, Deuteronomy and the Hermeneutics of Legal Innovation (New York and Oxford 1997), 10, 5397, esp. 95-97. The historical order of the two texts is not determinative for the point I am making here.

40. The word בספר, "in the scroll of," is not reflected in the LXX. On the differences between MT and LXX in these verses see Kristin de Troyer, 'Building the Altar and Reading the Law: The Journeys of Joshua 8:30-35', in Kristin de Troyer and Armin Lange (eds), Reading the Present in the Qumran Library: The Perception of the Contemporary by Means of Scriptural 
has been used (זבח אבנים שלמות אשר לא־הניף עליהן ברזל)." And they offered on it burnt offerings to Yhwh (ויעלו עליו עלות ליהוה), and they sacrificed offerings of well-being (ויזבחו שלמים).

The narrator cites the 'law of Moses.' The closest parallel to the quotation is found in Deut. 27:5-8:

${ }^{5}$ Also you shall build an altar there [on Mount Ebal] to Yhwh (ובנית ... מזבח ליהוה) your God, an altar of stones [on which] you have not used an iron tool (מזבח אבנים לאזתניף אבנים) (עליהם ברזל (שלמות). Then offer up burnt-offerings on it to Yhwh (והעלית עליו עולת ליהוה) your God. ${ }^{7}$ Make sacrifices of well-being (וזבחת שלמים), and eat them there, rejoicing before Yhwh your God. ${ }^{8}$ You shall write on the stones all the words of this law very clearly. ${ }^{41}$

Interpretations (Atlanta 2005), 141-62.

41. Deuteronomy 27:5-7 (or 5-7a), regarding the altar, is often thought to have been inserted into an original instruction regarding inscribed stones (vv. 1-4, 8). Likewise, Joshua 8:30-35 is often taken to be intrusive to its context. Both texts develop instructions found in Exod. 20:2425 and 24:3-8, but their relationship to one another is fraught. (See e.g. Jean Louis Ská, 'Joshua 8:30-35: Israel Officially Takes Possession of the Land', in Reinhard von Achenbach and Martin Arneth (eds), 'Gerechtigkeit und Recht zu üben' (Gen 18,19): Studien zur altorientalischen und biblischen Rechtsgeschichte, zur Religionsgeschichte Israels und zur Religionssoziologie: Festschrift für Eckart Otto zum 65. Geburtstag [Wiesbaden 2009], 308-316; Julio C. Trebolle Barrera, 'A Combined Textual and Literary Criticism Analysis: Editorial Traces in Joshua and Judges', in Hans Ausloos et al., Florilegium Lovaniense: Studies in Septuagint and Textual Criticism in Honour of Florentino García Martinez [Leuven and Paris 2008], 437-463). It seems 
Joshua 8:30-31 is dissimilar to Deut. 27:5 in three ways. The morphology of the verb 'use' (נו"ף) differs slightly (H impf. 2d masc. sg. II $\mathrm{H}$ perf. 3d masc. sg.). Joshua 8:31 includes the relative particle אשר, which is unexpressed in Deut. 27:5. Whereas a 3d per. masc. pl. pronoun (הם-) appears in Deut. 27:5, Josh. 8:31 has a 3d per. fem. pl. pronoun (הבנים in in in in in in the quotation, the qualification found in Deut. 27:6 that the stone not be dressed ('whole,' שלמות) is integrated as part of the quotation, the rest of which was drawn from 27:5. It should also be noted that several phrases and clauses that lie outside of the quotation in Josh. 8, also appear in Deut. 27:5-7, further deviating from modern practices of citation:

Josh. 8:30 'built an altar to Yhwh,' יבנה ... מזבח ליהוה Deut. 27:5

Josh. 8:31 'they offered on it burnt offerings to Yhwh,' ויעלו עליו עלות ליהוה II Deut. 27:6

Josh. 8:31 'and sacrificed offerings of well-being,', ויזבחו שלמים II Deut. 27:7

Whether Deut. 27:5-7 is older than Josh. 8:30-31 and influenced its expression or whether the reverse is true is irrelevant to my point here. Joshua presents itself as a quotation of the law of Moses. A law that is remarkably similar in matters of content, verbiage, extent, and intent appears in Deut. 27:5-7. And yet the two iterations of the law manifest plusses, minuses, substations, adaptations, and rearrangements when compared with one another.

More extreme cases of dissimilarity are not uncommon. A classic example can be found in Jer. 17:21-22. The prophet quotes Yhwh on the subject of Sabbath law in language that is most

to me that Josh. 8 presupposes Deut. 27 or something very like it, because it is presented as the fulfillment of the command. In any case, the point that I made in n.39, regarding the relative dates of Deut. 16:1 and 2 Kings 23:21, is equally applicable in this case.

42. Some medieval mss, both Masoretic and eu, read עליהן in Deut. 27:5, coordinating the verse with Josh. 8:31. 
similar to Deut. 5:12-14a: ${ }^{43}$

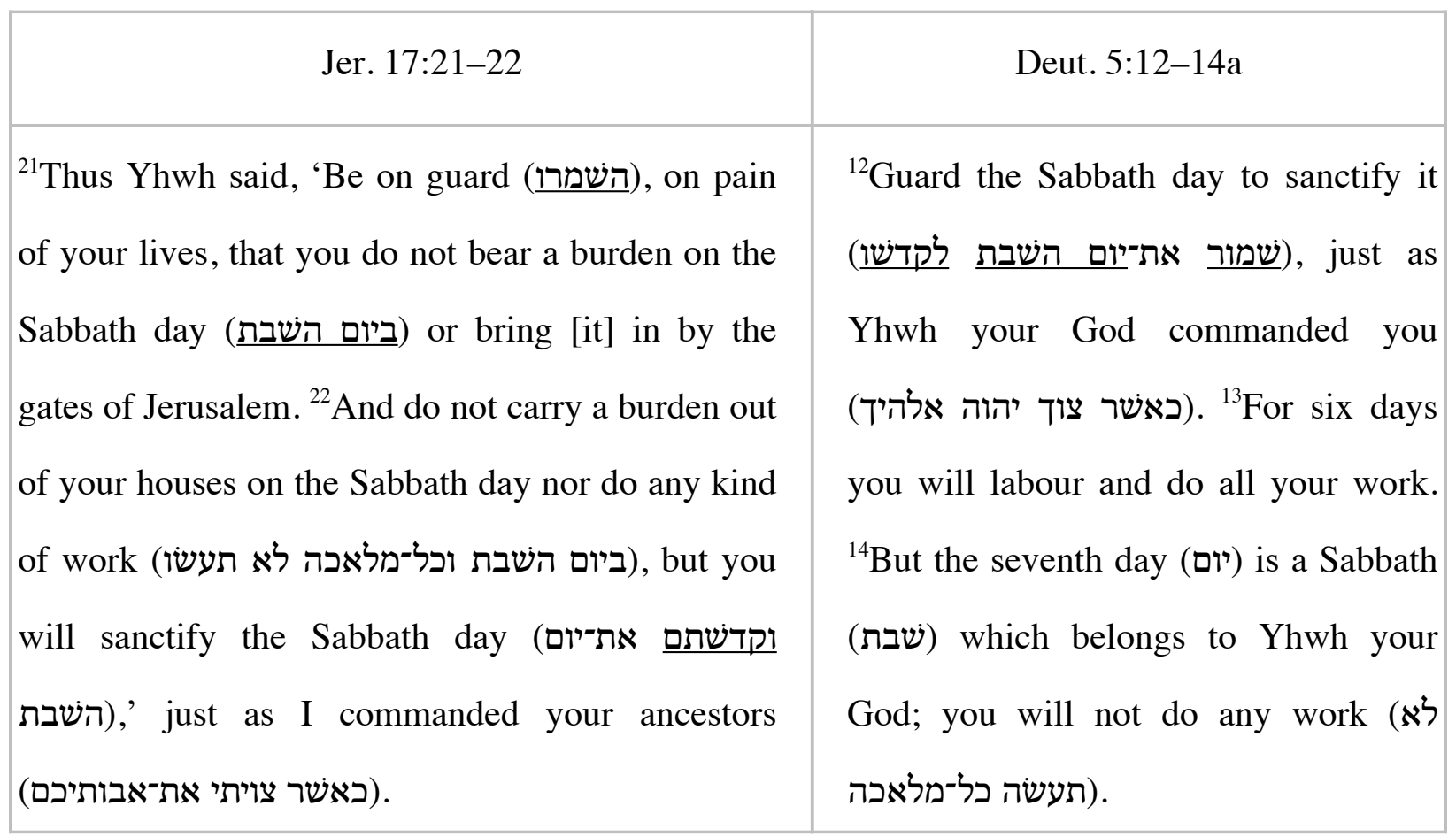

Structurally, this quotation is as discrete as any in the HB, being framed by כה אמר יהוה and שמ"ר,) (קד"ש (קט יום השבת, , repeating them in the same order but including expansions between each, which double the length of the quotation. (There are thirteen words shared by the two texts and

43. Michael Fishbane, Biblical Interpretation in Ancient Israel (Oxford, 1988), 132-34. That the quotation is likely to have been derived from Deut. 5 rather than Exod. 20 is indicated by the exhortative שמ"ר) (זכוכר Exod. uses), and the reference to the law having been given to the ancestors (Deut. 5:12b || Jer. 17:22b).

44. The first, כה אמר אדני, marks the beginning of the divine speech (vv. 17-27); the second, את־אבותיהם כאשר צויתי, is the quotation formula (v. 22). 
eleven additional words in Jer. 17:21-22). The expansions are mostly composed of locutions not found in Deut. 5:12-14a, but the second half of the expansion between וקדשתם and ביום השבת repeats Deut. 5:14aß, inverting the elements in accord with Seidel's law (לא תעשה כל־מלאכה > וכל־מלאכה לא תעשון). Not all the words from Deut. 5:12-14a are replicated in Jer. 17. The reference to six days of work and the affirmation that the Sabbath belongs to Yhwh as a sacred day were omitted. ${ }^{45}$ Also, the closing frame of the quotation, "just as I commanded your ancestors' (Jer. 17:22b, כאשר צויתי את־אבותיכם) is a rewording of Deut. 5:12b כאשר צוך יהוה אלהיך). Finally, the borrowed lemmata differ slightly from their source. The voice has been changed. Deuteronomy 5 is expressed in Moses' voice. Jeremiah 17 is in Yhwh's voice, reported by the prophet. The morphology also differs slightly. The law in Deut. 5 is addressed in the $2 \mathrm{~d}$ per. sing., whereas Jeremiah uses the pl.

Apart from the expansions, these differences attenuate Deut. 5:12-14a and adapt it to its new literary context. The expansions serve to elaborate on the Sabbath prohibition, banning 'carrying,' 'bringing out,' or 'bringing in' burdens on the Sabbath day. ${ }^{46}$ Fishbane characterizes

45. The equivalent for 'as Yhwh your God commanded you' (v. 12) appears in the quotation formula (Jer. 17:22b). The clause 'you will labour and do all your work' (v. 13) is not replicated, but two of its three words (מלאך עשך"ה) reappear in Jer. 17:21-22.

46. It has been suggested that the expansions were inspired by Exod. 16:13-30, the story of gathering and cooking manna on the Sabbath (vv. 23, 25), in particular by Moses' exhortation that the Israelites not leave their tents on the Sabbath (v. 29). As Shaye Cohen has observed, though, if the author of Jer. 17 was aware of Exod. 16:29, he does not interpret it as a universal regulation. The Jeremianic writer does not prohibit traveling or departing one's house on the Sabbath ('Sabbath Law and Mishnah Shabbat in Origen De Principiis,'Jewish Studies Quarterly 17 [2010], 160-189, observation at 177). Nehemiah 13:15-16 appears to interpret the carrying 
Jer. 17:21-2 as a 'pseudo-citation' because of its lack of identicality with Deut. 5:12-14a, overlooking the normalcy of dissimilarity in citations.

In our first examples, drawn from Genesis, the writers almost certainly had the words being quoted before them. One might dispute whether or not this is the case for the quotations in 2 Kings 23, Josh. 8, and Jer. 17. My main point, though, is this: both quotations, which are crafted during the process of composition, and citations, which are presented as iterations of older textual material, are attempts at replication on a smaller scale but in the same way that copying a manuscript is an attempt at replication. Whether the writers providing these replications had a written source to hand or not, their replications exhibit dissimilarities. In short, dissimilarity appears to have been a prominent and productive feature of communication-replication in ancient Hebrew literature. Moreover, the same types of dissimilarity feature in all of our examples, dissimilarities that are the common fare of textual-criticism and translation-technique: (1) morphology may be adjusted to suit the new communication context (contextual interference); (2) the quotation may include syntactic markers, words, phrase, and clauses unexpressed in the source (addition); (3) the quoted lemma may be comprised of elements drawn from different verses, if not different chapters or books (conflation); (4) in citations, it is not unusual for a word to be exchanged for a substitute, usually one of its synonyms (word

prohibition as a ban on porting merchandise for sale. For a discussion of subsequent interpretations of Jer. 17, including Neh. 13, see Alex P. Jassen 'Tracing the Threads of Jewish Law: The Sabbath Carrying Prohibition from Jeremiah to the Rabbis', Annali di storia dell'esegesi 28:1 (2011), 253-78. Expansions and adaptation of Sabbath law are hardly irregular in the HB. In addition to Jer. 17:19-27 and Neh. 13:15-16, see Amos 8:5; Isa. 58:13-14; Neh. 10:32. 
substitution); (5) finally, the words quoted need not be an inclusive sequence; words can be purposefully missed out (omission). These basic types of dissimilarity appear to be typical and persistent across all types of textual replication irrespective of the medium of the source or the intention of the writer (to compose or transmit), and whether the material replicated was accessed from memory, or read aloud to the writer, or read from a physical copy.

\subsection{Implications}

It is difficult to exaggerate the importance of scholarship on the dynamics of orality and textuality in ancient Hebrew scribal culture. The topic has stimulated numerous monographs, articles, and research groups on 'orality and textuality' in ancient Israel. Within this research area it has fallen to Person and Carr to articulate its implications for textual criticism, and they have done much to add nuance to the analysis of oral- and memory-variants.

Nevertheless, the evidence from two other types of textual reproduction-quotations and inner-biblical citations - does not join up perfectly with their proposals. Dissimilarity is the norm with quotations and citations, and the types of dissimilarity generated by quotations and citations are identical to types of dissimilarity that Person and Carr identify as aural- or memory-variants. In the examples rehearsed in the second part of this essay, we observed many differences that might otherwise be interpreted as aural or memory variants (e.g., substitutions of sound-alike words, rearrangement of elements, word-substitutions, addition and omission of particles). Even in cases where the writer had the replicated words to hand in written form, the reproduction manifested the same types of dissimilarity that we might anticipate in cases where writers cite from memory. As such, we cannot readily distinguish oral- and memory- variants from copying variants. While I have no doubt that oral- and memory-variants are present in many if not most manuscripts and rewritten texts, we do not yet possess the diagnostic tools for authenticating 
them. In most cases, the medium from which the source of a replication is drawn is unknown. It may have been embedded in memory, read aloud to the writer, or copied from a page. We may suppose that we know or we may have good guesses about the medium, but our knowledge is occluded. As a result, when considering variations between sources and their textual reproductions we can only describe the differences that we see and the literary effects of those differences. Without unambiguous knowledge of the medium of a source, we lack the diagnostic tools to identify the causes of the differences. ${ }^{47}$

Not only is dissimilarity the rule for all types of text-reproduction, but the examples above show that there is no discernible difference between the kinds or frequency of dissimilarities produced in text-production and those produced in text-transmission. ${ }^{48}$ Many supposed oral- and memory-variants observed by Person and Carr were created in the course of transmission, of copying or translating. These variants manifest the same types of dissimilarities that were created during original composition, as is the case with quotations. Inner-biblical citations stand

47. Among textual-critics, some remain unconvinced that 'memory variants' make up a significant class. For example, Emanuel Tov asserts that 'There is no reason to assume scribes who knew their biblical text well wrote them from memory' (Scribal Practices and Approaches Reflected in the Texts Found in the Judean Desert [Studies on the Texts of the Desert of Judah 54, Leiden 2004], 11).

48. There are, of course, any number of theoretical and phenomenological problems with the binary distinction transmission/copying vs. composition/writing, on which there is a wide body of scholarly literature. See, recently and extensively, D. Andrew Teeter, Scribal Laws: Exegetical Variation in the Textual Transmission of Biblical Law in the Late Second Temple Period. (Forschungen zum Alten Testament 92, Tübingen 2014), 6-29, 173-199. 
somewhere in between these two poles. They are presented as copies, replications of existing textual matter, but they are created as part of the composition process. In other words, the literary convention of dissimilarity appears to be persistent, a pervasive feature of text replication in Jewish antiquity

Though this conversation has been carried out largely in the domain of biblical studies, it is no less pertinent to other fields of ancient Hebrew literature. In 1993, Edward Greenstein suggested that the frequent 'misquotations' of scripture in the Dead Sea scrolls were due, quite often, to memory lapses rather than text forms alternative to the proto-MT. ${ }^{49} \mathrm{He}$ examined supposed 'misquotations' in the Great Isaiah Scroll (1QIsa'), Hodayot (1QH), the Pesher Habakkuk (1QpHab), 4QTestimonia, Deuteronomy (4QDeut $\left.{ }^{\mathrm{h}}\right)$, Psalms (4QPsa $\left.{ }^{\mathrm{b}}, 11 \mathrm{QPsa} \mathrm{a}^{\mathrm{a}}\right)$, and the Damascus Covenant (CD). His examples were drawn from different kinds of textual replications. Some were taken from copies of biblical manuscripts (e.g. 1QIsa $)$. Others were from Second Temple compositions that rewrite, cite, or allude to scripture (e.g. CD). In every case, he attributed the dissimilarity to scribes who 'wrote down scripture from memory. ${ }^{, 50}$ Nor was Greenstein alone. He gleaned his examples from works by Harry Orlinsky, E. Hammershaimb, Patrick Skehan, and Jan De Waard, among others. ${ }^{51}$ Moving beyond Hebrew

49. Edward Greenstein, 'Misquotation of Scripture in the Dead Sea Scrolls', in Berry Walfish (ed), The Frank Talmage Memorial Volume 1 (Haifa and Hanover, NH 1993), 71-83.

50. Ibid, 78 .

51. Harry Orlinsky, 'Studies in the St. Mark’s Isaiah Scroll', Journal of Biblical Literature 69 (1950), 149-166; E. Hammershaimb, 'On the Method Applied in the Copying of Manuscripts in Qumran', Vetus Testamentum 9:4 (1959), 415-18; Patrick W. Skehan, 'A Psalms Manuscript from Qumran (4QPsa ${ }^{\mathrm{b}}$ )', Catholic Biblical Quarterly 25 (1964), 313-22; Jan De Waard, 30 
literature, Christopher Stanley has suggested a similar model for explaining dissimilarities between the MT and New Testament quotations. ${ }^{52}$

It may be that the habit of dissimilarity that we see in textual reproductions did, in fact, originate in the vagaries of oral performance and memory. An analogy, perhaps, can assist. Textual features that may have originated from diachronic development or the processes of transmission do sometimes become, in a later time, techniques employed in the writing of new literature. The book of Tobit, for example, manifests features that have led some to posit a multilayered evolution for the book. In the first half of the twentieth century, doubts were raised about the originality of the references to Ahiqar $(1: 21-22 ; 2: 10 ; 11: 18 ; 14: 10)$ and chs 13 and parts of 14, in which Zimmermann detected anachronistic eschatological overtones and historical infelicities (e.g., regathering from diaspora and references to the temple) ${ }^{53}$ In the late twentieth century, there were two major attempts to reconstruct the book's redactional history, by Paul Deselaers (1982) and Merten Rabenau (1994). Both highlighted, in particular, syntactic and narratorial tensions that betray editorial activity. There are, for example, occasional unannounced changes in person or voice $(3: 7 ; 3: 16)$. Tobit $1: 20$ appears to be contradicted in $2: 1$. Two

Comparative Study of the Old Testament Text in the Dead Sea Scrolls and in the New Testament (Leiden 1965).

52. Christopher Stanley, "The Social Environment of "Free" Biblical Quotations in the New Testament', in Craig A. Evans and James A. Sanders (eds), Early Christian Interpretation of the Scriptures of Israel: Investigation and Proposals (Sheffield 1997), 18-27.

53. E.g., Frank Zimmermann, The Book of Tobit: An English Translation with Introduction and Commentary (Jewish Apocryphal Literature Series, New York 1971), 46. See also the earlier judgments of Robert Pfeiffer, History of New Testament Times: With an Introduction to the Apocrypha (New York 1949), 276. 
admonitions unexpectedly intrude into the story in chaps 4 and 12 . In chaps $6-11$, the angel's name switches without apparent reason between 'Raphael' and 'Azariah,' and the happy ending is unnecessarily revealed at early stages in the story $(3: 17 ; 6: 17) .{ }^{54}$ These observations are unimpeachable and, if they appeared in a biblical document, would inspire diachronic explanations. More recent scholarship on Tobit, however, has suggested that many of these tensions are the result of a rich matrix of allusions and narrative mimicry. Tobit's narrative is crafted as a complex engagement with (at least) Gen. $2-3,18^{*}, 19^{*}, 24$, and 29-35. One aspect of Tobit's mimicry is to replicate types of stylistic and narratorial incoherence that, in Genesis, may well have resulted from diachronic development. In the case of Tobit, though, the author has incorporated these infelicities into the repertoire of writing techniques. ${ }^{55}$ Something similar

54. Paul Deselaers Das Buch Tobit: Studien zu seiner Entstehung Komposition und Theologie (Orbis biblicus et orientalis 43, Freiburg and Göttingen 1982); Merten Rabenau, Studien zum Buch Tobit (Beihefte zur Zeitschrift für die alttestamentliche Wissenschaft 220, Berlin and New York 1994); so also David Flusser, 'Psalms, Hymns, and Prayers,' in Michael Stone (ed), Jewish Writings of the Second Temple Period (Compendia rerum iudaicarum ad Novum Testamentum 2, Philadelphia 1984), 551-77, esp. 556; John J. Collins, 'The Judaism of the Book of Tobit,' in Géza Xeravits and József Zsengellér (eds), The Book of Tobit: Text Tradition, Theology. Papers of the First International Conference on the Deuterocanonical Books, Pápa Hungary, 20-21 May, 2004 (Journal for the Study of Judaism Supplement Series 98, Leiden and Boston 2005), 25. See also the summary of the debate regarding the book's 'integrity' in Francis Macatangay, The Wisdom Instructions in the Book of Tobit (Deuterocanonical and Cognate Literature Studies 12, Berlin and New York 2011), 7-44.

55. See, for example, Lothar Ruppert, 'Das Buch Tobias—ein Modellfall nachgestaltender 32 
might be operative in our case. That is, dissimilarities that may well have originated in aural or mental causes have become compositional techniques employed by ancient writers in the production and replication of texts. Dissimilarities serve, at a minimum, a mimetic function: to add a dimension of 'realism' to a story. ${ }^{56}$ In more complex cases, like Jer. 17:21-22, the convention sanctions and undergirds complex exegetical interactions between text-segments. I do not suggest that this is, in fact, how the habit of dissimilarity arose. I merely propose that explanations other than aural and memory errors can account for the dissimilarities that characterize textual replication in ancient Hebrew literature.

In conclusion, evidence from quotations and inner-biblical citations is relevant to our understanding of the relationship of orality, textuality, and memory. The examples offered above (and there are dozens, if not hundreds, of similar examples ${ }^{57}$ ) indicate that dissimilarity between a source and its replication cannot readily be attributed to faulty recollection or the peculiarities

Erzählung,' in Josef Schreiner (ed), Wort, Lied und Gottesspruch: Beiträge zur Septuaginta Festschrift für Joseph Ziegler (Forschung zur Bibel 1, Würsburg 1972), 113-17; Daniel A. Bertrand, 'Le chevreau d'Anna: La signification de l'anecdotique dans le livre de Tobit,' Revue d'histoire et de philosophie religieuses 68 (1988), 269-74; Steven Weitzman, 'Allusion, Artifice, and Exile in the Hymn of Tobit', Journal of Biblical Literature 115:1 (1996), 49-61; Irene Nowell, 'The Book of Tobit: An Ancestral Story', in Jeremy Corley and Vincent Skemp (eds), Intertextual Studies in Ben Sira and Tobit: Essays in Honor of Alexander A. Di Leila, O. F. M. (Catholic Biblical Quarterly Monograph Series 38, Washington, DC 2005), 3-13; Tzvi Novick, 'Biblicized Narrative: On Tobit and Genesis 22', Journal of Biblical Literature 127 (2007), 75564. Some of these observations were anticipated already in the nineteenth century by Israel Abrahams, 'Tobit and Genesis', Jewish Quarterly Review 5 (1892-93), 348-350.

56. As has been observed by Kawashima, Death of the Rhapsode, 65, 80-81, 99-103, etc. 
of oral transmission. An author, placing the same utterance in the mouths of two characters (or twice in the mouth of single character) will typically render that utterance with difference. ${ }^{58}$ Difference is, if anything, even more characteristic of inner-biblical citations. This serves as a note of caution about too readily drawing conclusions regarding the causes of dissimilarity or the process of recall implied by them and cautions against overestimating the presence and significance of oral and mental features in biblical and Second Temple literature. ${ }^{59}$

57. For example: Gen. 3:17 || 2:16-17; Gen. 24:37 || 24:3; Gen. 24:43 || 24:14; Gen. $42: 33$ || 42:19; Num. 14:18 || Exod. 34:6-7; Num. 23:36 || 22:20; 24:13 || 22:18, 38; Judg. $13: 7$ || 13:3-5; 1 Sam. 15:18 || 15:2-3; 1 Kings 12:10 || 12:4. Additional examples can be found in George Savran, Telling and Retelling, esp. 18-36.

58. It should be noted that this is normal to reported speech in the HB whether quoted or not. See Miller, Representation of Speech, 61-91, esp. 74-90; Kawashima, Death of the Rhapsode.

59. My thanks to Larry Hurtado for directing my attention to his 'Oral Fixation and New Testament Studies? "Orality," "Performace" and Reading Texts in Early Christianity', New Testament Studies 60:3 (2014), 321-40 in which he sounds a similar caution with respect to NT studies and performance criticism. 